\title{
The Feasibility of Participatory Democracy -Examination of the Influence of the Phenomenon of Registration to Parties in Israel on the Level of the Citizen's Political Participation
}

\author{
David Schwartz ${ }^{\text {, Daniel Galily }}{ }^{2}$ \\ ${ }^{1}$ The Department of Political Science, Bar-Ilan University, Ramat Gan, Israel \\ ${ }^{2}$ Los Angeles University, Los Angeles, CA, USA \\ Email: daniel.galily@gmail.com
}

How to cite this paper: Schwartz, D., \& Galily, D. (2017). The Feasibility of Participatory Democracy. Open Journal of Political Science, 7, 276-282.

https://doi.org/10.4236/ojps.2017.72022

Received: November 25, 2016

Accepted: April 17, 2017

Published: April 20, 2017

Copyright $\odot 2017$ by authors and Scientific Research Publishing Inc. This work is licensed under the Creative Commons Attribution International License (CC BY 4.0).

http://creativecommons.org/licenses/by/4.0/

\begin{abstract}
Joining a political party (and thus acquiring the right to vote of a far more restricted group for representatives in the Parliament) greatly increases the political power of the single person or an organized group of people and implements participatory democracy in a restricted forum in which the opinions of every citizen have significant political power (with emphasis on the organized groups). The moment of a person is a part of a far more restricted group with great influence, and then his political power increases and his voice during elections has greater importance.
\end{abstract}

\section{Keywords}

Participatory Democracy, Party Politics, Primaries

\section{Introduction}

The theory of participatory democracy is a theory in political science, the goal of which is the promotion of the level of public participation in different forums of public decision making in liberal democracy. This theory emphasizes the importance of a high level of political activity of civil society with the goal of broadening the number of participants in the processes of making decisions in the organization, in the community, in the state, and in the international system. This theory argues that the promotion of the level of political participation (to the maximal level) of all the citizens in the public spaces, in government frameworks, and in forums of the making of political decisions will lead to the development of the simple citizen.

In the system of relations between the citizen and the government in democratic states, the expressions of participatory democracy are apparent in actions 
such as participative budgets, referendums, initiatives of civic legislation, community managers, citizen committees, and many additional examples. The purpose of participatory democracy is to develop the citizen through the inculcation of knowledge and political experience and conversely to reduce the gaps existing between him and the government institutions and policy makers (Noyberger, 2004).

The roots of the theory of participatory democracy are found in direct Athenian democracy, which manages a political system through the personal and continuous voting of the citizens on the processes of legislation and policy. In addition, the proponents of the participatory approach quote the writings of political thinkers such as Rousseau, Mill, and Cole, who have argued that the citizen's participation in political discussions increases his level of political effectiveness and therefore causes him to be a better citizen (Pateman, 1970).

\section{Academic Literature}

In the academic literature the following question arose. Is participatory democracy possible? On this topic, two conflicting attitudes of two main researchers who examine this issue will be presented.

\section{Arguments for Participatory Democracy}

The researcher Amy Gottman believes that participatory democracy is problematic in terms of its reality but possible using different means such as referendums, with clearly visible advantages because it gives the people a direct relationship with their representatives and direct abilities regarding making the decisions that influence their lives. However, Gottman emphasizes that she is not interested in a return to the regime of direct democracy, which included the exclusion of women from the elementary right of voting and decision making.

Gottman presents participatory democracy as challenging the emphasis placed by the liberal democrats on the protection of civic rights in contrast to participation in politics. She adds that the participatory democrats maintain that significant political participation will cause the citizens to make their voice heard and to reach political decisions to a great extent, when today many avoid any participation in the political system.

According to Gottman, the proponents of participatory democracy see Athenian democracy as the model, and especially the Athenians' distaste for a life that is completely private, which includes additional opportunities for participation, and not only the choice of representatives every few years, as the ideal to which they aspire. However, she emphasizes that this is not from nostalgia for the Athenian period, a period of a regime of slaves and exclusion of women from the political process.

According to Gottman, there is necessity for elements of participatory democracy since democracy of representatives suffers from a number of deficiencies, all outcomes of the method of representation in contrast to participatory democracy: the representatives lack political understanding and knowledge, there are low rates of voting, and there is a level of corruption and breach of 
trust of the representatives.

The supporters of participation hope that the opportunity to influence will lead to the broadening of the citizen's knowledge on the political process. Although Gottman is skeptical on the topic and maintains that the citizen will not want to invest the effort, she believes that the political participation is a part of the person's good life and it will be possible to reach a general recognition of this under the right conditions. Participatory democracy is required to prevent the abuse of the power of the public representatives (Gottman, 1993).

\section{Arguments against Participatory Democracy}

In contrast to Gottman, Norman Bary presents a number of arguments against participatory democracy as a possible solution for problems of liberal democracy. Bary does not believe in the approach of participation as a possible solution for different issues. Bary holds that radical critics of democracy turned to collectivist solutions. When the public's elected representatives argued that it is necessary to solve problems of democracy through the reduction of the government's range of action, the socialists tended to broaden the range of action but to demand the change of the method of action. The threat set by "large government" to individual freedom and equality can be removed through the decentralization of the government's power to smaller units, on a local and regional basis. This theory is called the demand for greater "participation".

Bary maintains that the proponents of "participation" assert that political equality is denied in a competitive democratic political method since the citizen's activity is restricted to the choice between leaders from time to time. They suggest that the political participation be ongoing activity. Therefore, if the making of decisions shifts from the main government to local bodies, then this will allow individuals and groups to create laws and policy that directly address their interest.

However, Bary holds that the assumption that human nature will be more moral through a process of democratic consultation and social exchanges is erroneous. He believes that there is no guarantee of the fact that the making of decisions in small societies will be more restrained than that in large societies.

He adds that the politicization of social life will act for the good of those who have the possibility of controlling public life and the elites can appear and control the participatory system. He adds that few thinkers in the participatory approach think to decentralize the power to the level of the individual and the participatory approach does not address the traditional democratic mechanismthe separation of authorities, the rule of law, judgmental criticism of legislation, and so on. He summarizes that it is possible to assume that indifference is an important characteristic of democratic life and in essence the high participation results of elections are a characteristic of unstable regimes (Bary, 1989).

\section{Research Hypothesis}

The research hypothesis is that elections in which only party members and not 
all the public choose the party list for the Parliament constitute a field for participatory democracy and direct participation in practice. Since a more limited number of people from the public has the possibility to choose representatives for the national parliament, it is important to these candidates for parliamentary representation to satisfy and convince these party members, thus giving considerable political power to every party member and/or group of members in the party relating to the representatives' decisions. Thus, the disconnection, which Gottman addressed, between the representative and his voters is removed, although the representative does not see the regular citizen to have political importance since he is one of many similar ones in the population, he does not see the party member at the same level of importance since the same member is one of a more limited number of people who can influence his political position.

\section{Participatory Democracy through the Registration to Political Parties in Israel}

Today in Israel there are three parties that give voting right to all the people who register to the internal party elections that determine the candidates of the party for the Knesset and the party chair. Originally, the party that brought the method to the Jewish community in the Land of Israel was the Mapai Party, which gave all of its members the right to vote for the different candidates of the party, from the socialist ideal of equality. All the other parties only gave the party center or a special committee the right to choose the candidates (Galnor, 1985). In 2005 when the Kadima party was established, it implemented this approach (The Kadima Party Website, 2009), and in 2006 the Likud Party joined it, when it passed a decision in the Likud Center that transfers the right to choose Knesset members and the party chair from the members of the Likud Center to all the Likud registered members (The "Jewish Leadership" Faction in the Likud Party Website, 2007).

The article presents two examples of certain groups in the population with an interest that did not succeed in convincing the public representatives to implement their interest for many years because their number did not have political importance relative to all the population. It is further noted in these examples that after these interest groups registered thousands of members to the ruling party, their political power increased, as perceived by the representatives and by different persons of influence in the ruling party, thus assisting them in bringing their own representatives to a position of influence in the party.

Although there are three parties that implement the principle of the right of choice of the party representatives to the Knesset for all the members, the examples will focus on the Likud Party, since it is the current ruling party and therefore has the greatest influence.

\section{Registration of the Motorcyclists to the Likud Party}

The first example is that of the motorcyclists' struggle. The motorcyclists had struggled for ten years against the increase of the expensive insurance premiums 
set by insurance companies for the motorcyclists. This protest raised sweeping support in the public of the idea of the struggle, which included sympathetic coverage in the media and sympathetic statements from different organizations in the public, but not from ministers in the different governments that objected to legislation on the matter or ignored the struggle. Only when in the tenth year of the struggle the Association of Motorcyclists registered approximately one thousand motorcyclists to the Likud Party were sympathetic statements of different people in the Likud Party voiced and objections to the different initiatives were not raised on the part of senior party officials.

After about fourteen months, Knesset member Carmel Shama adopted another issue: he took upon himself willingly and voluntarily the job to lead in the Knesset the struggle of the motorcyclists for fair insurance prices, although he was not a motorcyclist and he did not have a motorcycle license and he was not promised anything. Therefore, members of the motorcyclists' association concluded that the action was caused because of the process of organized registration to the Likud.

This had immediate responses. The motorcyclists' lobby in the Knesset, which was led by Knesset member Shama, submitted a law proposal that reduced the costs of insurance to a sane level, equal for all pockets. Under the pressure of the lobby, the law proposal reached the Ministerial Committee for Legislation, was passed there, and immediately was transferred to the Knesset for voting in the preliminary hearing, where it passed ("Full Gas" News Website, 2010).

\section{Registration of the Israel Aircraft Industry Workers to the Likud Party}

The second example addresses the mass registration of the workers of the Israel Aircraft Industry to the Likud Party. The process of registration commenced in 1992 and included the public of retired workers of the Israel Aircraft Industry. The advantage was that all the workers came as one to the voting booth on the day of the internal elections of the party and voted according to explicit directives. The final outcome of this process of organized registration was that the Chair of the Workers Committee, Haim Katz, was chosen regularly to the Israeli Knesset and worked in it for the public of people in the population from which the public of workers of Israel Aircraft Industry came.

As a result of Haim Katz's presence in the Knesset, his activity following the registration for the rights of the workers and the elderly was very extensive. As the Chair of the Committee of Labor, Welfare, and Health of the Knesset, he passed social laws and law amendments that benefited the weak populations (Haaretz Newspaper, 2011).

The registration and blind voting of all the workers and retired workers of Israel Aircraft Industry for Haim Katz caused him not to be afraid of any other politician, not of the Prime Minister, not of the Minister of Finance, and not of the senior officials in the Ministry. Over the years Katz, has acquired the image of a political bully, because of his rudeness and since behind him there were 
thousands of workers of the Israel Aircraft Industry who supported him since he was first elected to the Committee Chair in 1992, a position to which he continues to be elected regularly.

Kataz, as many in the political and financial system note, is in practice the strongest person in Israel Aircraft Industry. Haim Ben-Shalosh, the Chair of the Comitee of the Tadiran-Telcom Company said, "He brought the Workers' Committee of the Israel Aircraft Industry to heights that I envy. We called him Napoleon - short, strict, and a bastard. He is not a person you can hang out with." (Haaretz Newspaper, 2011).

\section{Summary}

A reservation should be noted: a direct relationship between the voter's desires and his representatives, which constitutes an ideal of participatory democracy, exists through the registration to the party but it does not exist all for the general public. Participatory democracy is applicable in centralized and small organizations, like political parties, but the voice of the simple citizen is not yet heard because of the small scale of his political power (one of millions).

However, it should be noted that at the moment that his political power increases, a normal person can go and make a representative demand he could not make if he was a regular citizen. In addition, in different assemblies the registered person can raise topics in a far more restricted forum in the presence of a senior person in his party than in the presence of the members of the limited forum. The registered person has a direct access to the senior person and can voice his opinions, when as a citizen he would not receive this. There is greater willingness, on the representative's part, to listen to the registered member's opinions and to act according to them.

In my opinion, this reality creates a basis for the implementation in practice of participatory democracy. In other words, this is the democracy in which every member has direct access to his representatives and sufficiently strong political power that enables him to require of his representatives to execute a policy and/or legislate laws according to his opinion. Moreover, every registered member has the possibility of influencing an unlimited number of other registered party members, whether through opinions in forums and assemblies of the party or through personal conversations with other members. The representative is aware of this and therefore is interested in making certain that this member will be satisfied with his different actions.

In addition to individual registration, there is the mass registration of associated interest groups to different parties. Every candidate or representative on behalf of any party knows that a large group of people, party members, with the same few interests and with the power of "collective voting", can constitute a very large political force in the internal party elections, far more than groups of the same size of regular citizens. Examples were presented of the law proposals to reduce the insurance premiums for motorcyclists, which followed the collective registration of thousands of motorcyclists to the Likud Party, and the party 
immunity of Haim Katz in the Likud following the discipline and power of the Workers Committee of the Israel Aircraft Industry through its workers and retired workers who are Likud members with voting rights.

Therefore, it can be concluded that the influence is strong. Joining a political party (and thus acquiring the right to vote of a far more restricted group for representatives in the Parliament) greatly increases the political power of the single person or an organized group of people and implements participatory democracy in a restricted forum in which the opinions of every citizen have significant political power (with emphasis on the organized groups). The moment of a person is a part of a far more restricted group with great influence, and then his political power increases and his voice during elections has greater importance.

\section{References}

"Full Gas" News Website, from December 2, 2010.

Bary, N. (1989). Introduction to Modern Political Theory, in Course Reader: Contemporary Democratic Theories (pp. 7-9). Israel: The Open University Press. https://doi.org/10.1007/978-1-349-20201-0

Galnor, Y. (1985). Politics and Democracy in the Jewish Community and in the State of Israel. In: The Beginning of Israeli Democracy (Tel Aviv: Am Oved, 1985), 66-69.

Gottman, A. (1993). Democracy in Course Reader: Contemporary Democratic Theories (pp. 171-172). Israel: The Open University Press.

Haaretz Newspaper, March 16, 2011.

Haaretz Newspaper, The Marker Supplement, November 22, 2011.

Kadima Website, Movement Code, from the Date December 31, 2009.

Noyberger, B. (2004). Democracies and Dictatorships: Ideas, Contexts, Regimes (pp. 115-121). Israel: The Open University Press.

Pateman, C. (1970). Participation and Democratic Theory (pp. 22-44). Israel: Cambridge University Press. https://doi.org/10.1017/CBO9780511720444.002

The "Jewish Leadership" Faction in the Likud Party Website, from the Date December 26, 2007.

\section{Submit or recommend next manuscript to SCIRP and we will provide best service for you:}

Accepting pre-submission inquiries through Email, Facebook, LinkedIn, Twitter, etc.

A wide selection of journals (inclusive of 9 subjects, more than 200 journals)

Providing 24-hour high-quality service

User-friendly online submission system

Fair and swift peer-review system

Efficient typesetting and proofreading procedure

Display of the result of downloads and visits, as well as the number of cited articles

Maximum dissemination of your research work

Submit your manuscript at: http://papersubmission.scirp.org/

Or contact ojps@scirp.org 